\title{
PROSPECT guidelines update for evidence based pain management after prostatectomy for cancer
}

Running title: Pain management after prostatectomy

Adrien LEMOINE ${ }^{1 *}$, Annemijn WITDOUCK ${ }^{2}$, Hélène BELOEIL ${ }^{3}$, Francis BONNET ${ }^{4}$ on behalf of the PROSPECT working Group of the European Society of Regional Anaesthesia and Pain Therapy (ESRA)

${ }^{1}$ Consultant 4 Professor, Anaesthesia - Intensive Care and Peri-operative medicine Department, Hôpital Tenon, APHP, Paris, France/Médecine-Sorbonne Université, Paris, France

${ }^{2}$ Resident, Department of Cardiovascular Sciences, KU Leuven and University Hospital Leuven, Leuven, Belgium

${ }^{3}$ Professor, Université de Rennes, CHU Rennes, Inserm, INRA, CIC 1414 NuMeCan, Anaesthesia and Intensive Care Department, F-35000 Rennes, France

*Corresponding Author: Adrien Lemoine

Service d'Anesthésie-Réanimation et Médecine Péri-Opératoire, Hôpital Tenon, 4, rue de la Chine, 75020 Paris, France

Email: adrien.lemoine@aphp.fr

Acknowledgment: $\mathrm{AL}$ and $\mathrm{AW}$ equally contributed to this manuscript and therefore share first authorship.

PROSPECT Working Group: E Albrecht, H. Beloeil, F. Bonnet, A Delbos, S Freys, A Hill, G. P. Joshi, H. Kehlet, P. Lavand'homme, P. Lirk, D Lobo, E. Pogatzki-Zahn, N. Rawal, J. Raeder, A. R. Sauter, S. Schug, M. Van De Velde 


\section{SUMMARY}

The aim of this review was to update the recommendations for optimal pain management after open and laparoscopic or robotic prostatectomy.

Optimal pain management is known to influence postoperative recovery, but patients undergoing open radical prostatectomy typically experience moderate dynamic pain in the immediate postoperative day. Robot-assisted and laparoscopic surgery may be associated with decreased pain levels as opposed to open surgery.

We performed a systematic review using Preferred Reporting Items for Systematic Reviews and Meta-Analysis (PRISMA) with PROcedure SPECific Postoperative Pain ManagemenT (PROSPECT) methodology. Randomised controlled trials (RCTs) published in the English language, from January 2015 until March 2020, assessing postoperative pain, using analgesic, anaesthetic and surgical interventions, were identified from MEDLINE, EMBASE and Cochrane Databases. Of the 1797 studies identified, 35 RCTs and 3 meta-analyses met our inclusion criteria. NSAIDs and COX-2 selective inhibitors proved to lower postoperative pain scores. Continuous intravenous lidocaine reduced postoperative pain scores during open surgery. Local wound infiltration showed positive results in open surgery. Bilateral transversus abdominis plane (TAP) block was performed at the end of surgery and lowered pain scores in robot-assisted procedures, but results were conflicting for open procedures.

Basic analgesia for prostatic surgery should include paracetamol and NSAIDs or COX-2 selective inhibitors. TAP block should be recommended as the first-choice regional analgesic technique for laparoscopic/robotic radical prostatectomy. Intravenous lidocaine should be considered for 
open surgeries.

Keywords: Prostatic surgery, robot surgery, postoperative pain, systematic review

\section{Recommendations}

1. Systemic analgesia should include paracetamol and selective or non-selective nonsteroidal anti-inflammatory drugs administered preoperatively or intraoperatively and continued postoperatively.

2. Continuous intravenous lidocaine is recommended during open surgery. Its use contraindicates the simultaneous use of infiltration with local anaesthetics.

3. Local wound infiltration should be used routinely for open surgery before other regional analgesia blocks, in the absence of intravenous lidocaine use.

4. Transversus Abdominis Plane block is recommended as the first-choice for laparoscopic/robotic radical prostatectomy.

5. Opioids should be used as rescue analgesics in the postoperative period.

\section{Why was this guideline developed?}

Prostatic surgery for cancer is associated with significant acute and chronic postoperative pain. The aim of this updated guideline is to provide clinicians with an evidence-based approach to pain management after oncological surgery, which may improve postoperative pain relief. 
A systematic review was performed by the PROSPECT collaboration in 2015; however, several new analgesic regimens, particularly regional analgesic techniques have been introduced since the previous systematic review and robot surgery has been developped on a larger scale.

\section{How does this guideline differ from other guidelines?}

The PROSPECT approach to developing guidelines is unique such that the available evidence is critically assessed for current clinical relevance. This approach reports true clinical effectiveness by balancing the invasiveness of the analgesic interventions and the degree of pain after surgery, as well as balancing efficacy and adverse effects.

\section{Résumé}

L'objectif de cet article est de mettre à jour les recommandations concernant la prise en charge optimale de la douleur après prostatectomie radicale.

La prise en charge optimale de la douleur a une influence sur la réhabilitation après chirurgie, mais les patients présentent souvent des douleurs dynamiques après une prostatectomie radicale. La chirurgie robotisée et laparoscopique peut être associée à une diminution des niveaux de douleur par opposition à la chirurgie à ciel ouvert.

Nous avons effectué une revue systématique en utilisant le Preferred Reporting Items for Systematic Reviews and Meta-Analysis (PRISMA) avec la méthodologie PROcedure SPECific Postoperative Pain ManagemenT (PROSPECT). Des essais contrôlés randomisés (RCTs) publiés en anglais, de janvier 2015 à mars 2020, évaluant la douleur postopératoire, utilisant des 
interventions analgésiques, anesthésiques et chirurgicales, ont été identifiés à partir des bases de données MEDLINE, EMBASE et Cochrane.

Sur les 1797 études identifiées, 35 RCT et 3 méta-analyses répondaient à nos critères d'inclusion. II s'est avéré que les AINS et les inhibiteurs sélectifs de COX-2 abaissaient les scores de douleur postopératoire. La lidocaïne intraveineuse contribue à réduire les scores de douleur postopératoire lors de chirurgies ouvertes. L'infiltration locale de la cicatrice a montré des résultats positifs en chirurgie ouverte. Le bloc bilatéral du plan transverse de l'abdomen (TAP) réalisé à la fin de la chirurgie a réduit les scores de douleur dans les procédures assistées par robot, mais les résultats étaient contradictoires pour les interventions chirurgicales à ciel ouvert. L'analgésie de base pour la chirurgie prostatique doit inclure le paracétamol et les AINS ou les inhibiteurs sélectifs de COX-2. Le bloc TAP bilatéral doit être recommandé comme technique analgésique régionale de premier choix pour la prostatectomie radicale laparoscopique/robot assistée. La lidocaïne intraveineuse doit être envisagée pour les chirurgies ouvertes.

\section{Recommandations}

1. L'analgésie systémique doit inclure le paracétamol et les anti-inflammatoires non stéroïdiens sélectifs ou non sélectifs administrés en préopératoire ou peropératoire et poursuivis en postopératoire.

2. La lidocaïne intraveineuse continue est recommandée pendant la chirurgie ouverte. Son administration contre-indique l'utilisation simultanée d'une infiltration avec les anesthésiques locaux. 
3. L'infiltration locale de la plaie doit être systématique pour une chirurgie ouverte, devant d'autres blocs d'analgésie régionale, en absence d'utilisation de lidocaïne intraveineuse.

4. Le TAP bloc est recommandé comme premier choix pour la prostatectomie radicale laparoscopique/robotique.

5. Les opioïdes doivent être utilisés comme analgésiques de secours pendant la période postopératoire.

\section{Pourquoi cette directive a-t-elle été élaborée?}

La chirurgie prostatique du cancer est associée à une douleur postopératoire aiguë et chronique importante. Le but de cette directive mise à jour est de fournir aux cliniciens une approche factuelle de la gestion de la douleur après une chirurgie oncologique, qui peut améliorer le soulagement de la douleur postopératoire.

\section{Quelles autres recommandations sont disponibles sur ce sujet?}

Une revue systématique a été réalisée par le groupe PROSPECT en 2015 ; cependant, plusieurs nouveaux schémas analgésiques, en particulier des techniques analgésiques régionales, ont été introduits depuis la revue systématique précédente et la chirurgie robotique a été développée à plus grande échelle.

\section{En quoi cette directive diffère-t-elle des autres directives ?}

L'approche PROSPECT pour l'élaboration de lignes directrices est unique, de sorte que les preuves disponibles sont évaluées de manière critique pour leur pertinence clinique actuelle. 
Cette approche apporte une véritable efficacité clinique en équilibrant le caractère invasif des interventions analgésiques et le degré de douleur après la chirurgie, ainsi qu'en équilibrant efficacité et effets indésirables. 


\section{INTRODUCTION}

Prostatic cancer is one of the leading cancers worldwide, accounting for $15 \%$ of cancers diagnosed in men [1]. There are a variety of treatment options for localised prostatic cancer including radical prostatectomy. Radical prostatectomy is recommended as a front-line treatment for men diagnosed with localised prostatic cancer and a life expectancy of more than 10 years [2]. Next to open radical prostatectomy, laparoscopic radical prostatectomy and robotassisted radical prostatectomy have been extensively developed [3].

Pain remains an important issue after radical prostatectomy resulting in patient' discomfort and sometimes prolonged hospital stay [4]. Optimal pain management is also known to influence postoperative recovery [5]. Patients undergoing open radical prostatectomy typically experience moderate dynamic pain in the immediate postoperative days [6]. Robot-assisted and laparoscopic surgery may be associated with decreased pain levels as opposed to open surgery [6]. However, trocar ports may be a source of parietal pain after robot surgery [7]. Due to significant variations in analgesic protocols, a unified approach is necessary to provide standardised interventions to reduce pain.

The PROSPECT (PROcedure SPEcific Postoperative Pain ManagemenT) Working Group includes surgeons and anaesthesiologists working to formulate procedure specific recommendations for pain management after common and potentially painful operations $[5,8]$. The recommendations are based on procedure-specific literature review of Systematic Reviews and Randomised Controlled Trials (RCT). The methodology considers clinical practice, efficacy and adverse effects of analgesic techniques [9]. (A) 
The aim of the current systematic review was to evaluate the available literature on the management of pain after radical prostatectomy. This review is an update of a previous PROSPECT review on radical prostatectomy published in 2015 [10]. This review also builds on evidences from the previous review to formulate new recommendations for pain management after radical prostatectomy. Postoperative pain outcomes (pain scores and analgesic requirements) were the primary focus, but other recovery outcomes, including adverse effects, were also assessed, when reported, and the limitations of the data were reviewed. The ultimate aim was to develop recommendations for pain management after radical prostatectomy. 


\section{METHODS}

\subsection{Search strategy}

This review was designed according to the PROSPECT methodology previously reported [9]. A systematic review of the literature associated with analgesia after robotic, laparoscopic and open prostatectomy was conducted. The Preferred Reporting Items for Systematic Review and Meta-Analysis Protocols (PRISMA-P) 2015 statement was used as a guide for this review [11]. EMBASE, MEDLINE, Pubmed and Cochrane Databases (Cochrane Central Register of Controlled Trials, Cochrane Database of Abstracts or Reviews of Effects, Cochrane Database of Systematic Reviews) were searched for studies published after database January 2015 until March 2020.

Search terms related to pain and interventions for laparoscopic prostatectomy OR robotic prostatectomy OR radical prostatectomy OR open prostatectomy AND pain OR pains OR pain management OR postoperative pain OR post-operative pain OR analgesi* OR anaesthe* OR anesthe* OR vas OR visual analog* OR vrs OR verbal rating scale* OR nrs OR numerical rating scale* OR pain rating OR epidural OR neuraxial OR intrathecal OR paravertebral OR spinal OR infiltration OR nerve block* OR neural block* OR paravertebral block* OR field block* OR Ilioinguinal block* OR transversus abdominis plane block* OR tap block* OR NSAID* OR nonsteroidal anti-inflammator* OR non-steroidal anti-inflammator* OR COX-2 OR Paracetamol OR paracetamol OR clonidine OR opioid* OR ketamine OR corticosteroid* OR gabapentin OR pregabalin. 


\subsection{Inclusion/exclusion criteria}

We included only randomised control trials (RCTs) and systematic reviews of analgesic, anaesthetic and operative interventions, published in English, assessing pain management for patients undergoing open, laparoscopic or robot-assisted prostatectomy. Studies that reported, in patients who underwent radical prostatectomy, pooled data combining other perineal and/or abdominal surgical procedures, and studies concerning non-radical prostatectomy, were excluded. The studies were also required to measure pain intensity using a numerical rating scale (NRS) or a visual analogue scale (VAS). In agreement with the PRISMA checklist, we analysed the potentially relevant studies in a step wise manner beginning by a screening of the abstracts [11]. Three reviewers $(\mathrm{AL}, \mathrm{AW}, \mathrm{HB})$ undertook this process reviewing the articles and compared their decisions. Any discrepancy between them was discussed within the working group and a decision was made on inclusion or exclusion by consensus. Three reviewers (AL, AW and FB) assessed the final articles, and again any discrepancy was settled in the same way. Reasons for exclusion were provided for each article. Reference lists of the relevant articles were screened to seek for any additional article that may has been missed in the initial literature search. This is how articles published before 2015 that were not assessed by the precedent review were also taken into consideration.

\subsection{Quality of included studies}

Quality assessment, data extraction and data analysis adhered to the PROSPECT methodology [9]. 
Criteria for assessment of the quality of eligible studies included allocation concealment (A adequate; B - Unclear; C - inadequate; D - not used), numerical (1-5) quality scoring system used by Jadad et al. to assess randomisation, double blinding and flow of patients, follow-up of more or less than $80 \%$ of the included patients, and whether the study met the requirements of the Consolidated Standards of Reporting Trials (CONSORT) 2010 Statement $[12,13]$.

\subsection{Analysis of outcomes and statistical analysis}

For each analysed study, summary information was extracted and recorded in data tables. This information included the surgical technique, the timing of surgery, pain scores, whether pain was assessed at rest or during mobilisation, supplementary analgesics used, time to first analgesic administration, time intervals between pain measurements and complications, if any. Same information was extracted from each meta-analysis included. Unless specified otherwise, it was assumed that the pain scores were assessed at rest. The systematic reviews were used to find additional studies via bibliographic screens as well as aid in formulating recommendations.

The included studies were grouped together based upon the analgesic interventions (e.g., epidural analgesia, peripheral nerve blocks, field blocks, surgical site infiltration, paracetamol, non-steroidal anti-inflammatory drugs, cyclooxygenase-2 specific inhibitors, etc.). Within each group, the studies were further placed into subgroups of preoperative, intraoperative, and postoperative interventions. The studies assessing the effects of surgical techniques on analgesic outcomes were grouped separately.

Pain intensity scores were used as primary outcome measures. We defined a change $>10$ $\mathrm{mm}$ on the Visual Analogue Scale (VAS) as clinically meaningful [14]. The effectiveness of each 
pain treatment for each outcome was evaluated qualitatively, by assessing the number of studies showing a significant difference between treatment arms $(P<0.05$ as reported in the study publication).

\subsection{Formulation of Recommendations}

Recommendations from the previous review were kept as baseline. New recommendations were given when at least two congruent studies support an intervention. Recommendations for optimal pain relief are graded A-D according to the overall level of evidence (LOE), as determined by the quality of studies included, consistency of evidence and source of evidence (Table S1). Recommendation grading is such as grade A stands for strong recommendation supported by multiples studies, with unanimous decision from Delphi rounds; grade B stands for intermediate recommendation supported by multiples studies, with majority decision during Delphi rounds; grade C lower strength recommendation based on few studies, with majority decision during Delphi rounds; grade D are weak recommendations based on few studies, downgraded by Delphi rounds. The group sought to determine the relevance of study interventions in current perioperative care practice, considering the risks and benefits, and critically evaluating the baseline pain treatment [9]. For qualitative analysis the trials were allocated to three broad groups: recommended interventions not recommended for routine use but may be considered if recommended interventions are not possible, and not recommended for routine administration.

The recommendations elaborated by the subgroup were sent to the whole PROSPECT Working Group for review and comments. A modified Delphi approach was used, including several 
rounds of individual comments followed by a round-table discussion. Once consensus was achieved the lead author drafted the final document, which was ultimately approved by the whole working group. 


\section{RESULTS}

The preferred reporting items for systematic review and meta-analysis (PRISMA) flow chart demonstrating the search are as per Figure 1. The previous PROSPECT review on radical prostatectomy included 38 studies. We used the same search criteria as before and opened the search to robot-assisted and laparoscopic prostatectomy and retrieved 35 new RCTs studies and 3 meta-analyses. Recommendation on analgesic interventions are summarised in Table 1, procedures not recommended are listed in Table 2 . The quality assessments of the studies included are summarised in Table 3. Open surgery was performed in 15 studies, a laparoscopic approach was performed in one study, and a robot-assisted laparoscopic approach was performed in 17 studies. Two studies considered the difference between robotic and open surgical procedures, and one study concerned fast track surgery. Key points of each study included in the analysis are summarised in table $\mathbf{S 1}$ (studies included in recommendations) and in Table S2 (studies not included in recommendation). Unless stated otherwise, every result described hereafter is statistically significant.

\subsection{Systemic non-opioid analgesia}

The analgesic effect of paracetamol was investigated in one placebo-controlled study for robotassisted prostatectomy. There was no difference in opioid use and pain scores, but the length of hospital stay was reduced in the paracetamol group [15].

The use of gabapentin was evaluated in one randomised controlled trial concerning open prostatectomy [16]. Gabapentin or placebo was given 2 hours before surgery while all patients received diclofenac and paracetamol. Compared to the controlled group, VAS scores were 
lower, tramadol consumption was comparable, and a lower number of patients required rescue analgesia in the group of patients having received gabapentin, without reported adverse effects.

The study of Weinberg et al. investigated the effect of a preoperative lidocaine intravenous bolus, followed by an intra-operative continuous intravenous infusion and a 24 hours postoperative subcutaneous infusion after open prostatectomy [17]. Patients received paracetamol, ketorolac and PCA morphine as baseline analgesia. Compared to the control group where patients received a saline infusion, VAS scores were lower at rest during the first 24 postoperative hours and at 24-hour morphine consumption was lower in the lidocaine group.

Ogric et al. compared an intraoperative $0.3 \mu \mathrm{g} / \mathrm{kg} / \mathrm{h}$ infusion of dexmedetomidine with placebo in open prostatectomy. Baseline analgesia in this trial consisted in paracetamol and a PCA piritramide. No difference was documented in pain scores and analgesics use [18].

Dirkmann et al. studied the effect of the postoperative use of the COX-2 selective inhibitor parecoxib. The use of parecoxib, compared to placebo, reduced the cumulative opioid consumption by $24 \%$ after open prostatectomy and decreased pain intensity [19].

\subsection{Regional anaesthesia}

Since July 2015, two new studies concerning spinal morphine for prostatectomy have been published. Bae et al. have compared 300 mcg of spinal morphine with intravenous morphine PCA as rescue with the standard of care provided by morphine IV PCA alone, for robot-assisted prostatectomy [20]. In the spinal morphine group, pain scores and postoperative 
morphine consumption were lower. There was no difference in side effects. The second RCT administered $200 \mathrm{mcg}$ of intrathecal morphine for open prostatectomy and found also a reduction in pain scores and a lower use of tramadol and rescue analgesia [21]. Basic analgesia was paracetamol, diclofenac and baseline analgesia of PCA tramadol. This study reported no adverse effect, other than pruritus, related to intrathecal morphine injection, and not even in statistically significant proportion. In a recent study, Koning et al. compared the intrathecal injection of $12.5 \mathrm{mg}$ bupivacaine and $300 \mathrm{mcg}$ morphine to a sham intrathecal injection before general anaesthesia in robot-assisted prostatectomy [22]. Patients received paracetamol, metamidazol and morphine PCA as baseline analgesia. Pain scores and postoperative opioid consumption were lower in the intervention group. None of these studies documented the duration of the effect of intrathecal morphine.

The effect of epidural analgesia was assessed in three studies. In all these studies the standard of care consisted in intravenous opioid PCA without mention of any basic analgesia. Baumunk et al. have compared thoracic epidural analgesia and general anaesthesia versus general anaesthesia alone during open prostatectomy. In the thoracic epidural group a bolus injection was given after insertion of the epidural catheter, and a continuous administration of bupivacaine was started. The authors documented lower pain scores measured on a numerical scale, on the first postoperative day in the thoracic epidural group [23]. Fant et al. also documented lower pain scores on coughing, during 24 hours after surgery, and a significant lower morphine postoperative consumption after open prostatectomy in their epidural group [24]. Hwang et al. have compared postoperative patient-controlled epidural analgesia (PCEA) with ropivacaine and morphine vs. intravenous PCA with nefopam $1 \mathrm{mg}$ and oxycodone $1 \mathrm{mg}$ 
during laparoscopic prostatectomy. Settings of PCEA were controlled to maintain vital signs within $20 \%$ of their basal levels with a 30 -minute lockout. Pain scores and cumulated consumption of local anaesthetic were lower in the PCEA group [25].

Chen et al. have investigated the effect of a caudal block on postoperative analgesia in robot-assisted prostatectomy. No decrease in pain scores and opioid use was documented [26].

Three randomised controlled studies have evaluated a bilateral TAP block in open prostatectomy. Elkassabany et al. have assessed the TAP block with $20 \mathrm{ml}$ of $5-\mathrm{mg} / \mathrm{ml}$ bupivacaine after induction of general anaesthesia. In the control group patients received a "sham block" performed with $20 \mathrm{ml}$ saline. Baseline analgesia was provided by IV morphine PCA in both groups, after a ketorolac administration at the end of surgery. VAS scores were lower during only 6 hours in the TAP block group [27]. Skjelsager et al. have compared TAP block, wound infiltration and placebo at the end of the surgery. Preoperatively, all patients received oral gabapentin, ibuprofen and paracetamol. Postoperatively patients received oral paracetamol and ibuprofen and IV patient-controlled analgesia with morphine. The first group had a bilateral TAP block with $20 \mathrm{ml}$ of ropivacaine $7.5 \mathrm{mg} / \mathrm{ml}$ on each side and a placebo wound infiltration, the second group had a surgical wound infiltration with $40 \mathrm{ml}$ of ropivacaine $07.5 \mathrm{mg} / \mathrm{ml}$ and a placebo bilateral TAP block, and the third group had a placebo bilateral TAP block and a placebo wound infiltration. They did not find a difference in pain scores or morphine consumption [28]. In the study of Maquoi et al., the TAP block, performed at the end of the surgical procedure, was compared to intravenous lidocaine continuous infusion during surgery, and to a placebo control group. The TAP block was performed with levobupivacaine, and patients in this group also had an intravenous bolus of saline. All patients received 
paracetamol during surgery and piritramide in the recovery room, then paracetamol in the wards and a piritramide patient-controlled analgesia as rescue. The intravenous lidocaine group had a $1.5 \mathrm{mg} / \mathrm{kg}$ bolus before induction followed by a continuous infusion of $2 \mathrm{mg} / \mathrm{kg} / \mathrm{h}$ until the end of the surgery, and in the placebo group saline was used both for the TAP block and the intravenous infusion. VAS scores and opioid requirement were comparable in the three groups [29]. None of these studies formally reported the TAP block effect duration.

Three randomised controlled studies have evaluated the TAP block in robotic surgery. Dal Moro et al. have compared a bilateral TAP block performed postoperatively with $200 \mathrm{ml}$ of $2.5 \mathrm{mg} / \mathrm{ml}$ bupivacaine with placebo [30]. Intraoperative opioids use was significantly lower in the TAP block group, together with a lower pain score and postoperative analgesic (tramadol and ketoprofen) requirements. Cacciamani et al. have compared a postoperative TAP block combined with wound infiltration to wound infiltration alone, and documented lower pain scores and analgesic requirements for tramadol when the TAP was combined with port sites infiltration [31]. Taninishi et al. have compared the use of a bilateral TAP block with placebo and found a significant difference in pain scores but a comparable morphine postoperative consumption [32]. None of these studies reported the TAP block effect duration.

Kristensen et al. used a subfascial catheter for open prostatectomy with a bolus of $2.5 \mathrm{mg} / \mathrm{ml}$ bupivacaine followed by an infusion of $5 \mathrm{ml} / \mathrm{h}$ of bupivacaine or saline and found a higher PCA morphine demand in the placebo group during the first two postoperative hours, but no difference in the total postoperative morphine use [33].

The efficacy of ultrasound-guided bilateral rectus sheath block with $20 \mathrm{ml}$ of $5-\mathrm{mg} / \mathrm{ml}$ bupivacaine was evaluated in open radical prostatectomy by Ibrahim et al. and compared with 
a placebo block; both groups had systemic analgesia with paracetamol and ketorolac, with morphine as rescue. A lower pain score and opioid use during the first day was documented in the rectus sheath block group [34].

Ntritsou et al. have compared postoperative electro-acupuncture versus sham acupuncture and documented lower NRS scores in the electro-acupuncture group and lower analgesic (tramadol and morphine) demand after open prostatectomy [35]. Weinberg et al. have studied the effect of dorsal penile nerve block with bupivacaine or saline for urethral catheter-related pain after open surgery. They documented lower abdominal pain score at $6 \mathrm{~h}$ postoperatively and but no difference at other time points [36].

A double-blind randomised placebo-controlled trial has compared intravesical instillation of 20 $\mathrm{ml}$ ropivacaine $10 \mathrm{mg} / \mathrm{ml}$ during one hour with placebo, after robot-assisted radical prostatectomy, and documented no effect on VAS scores and morphine use. However, there was a significant reduction in the cumulative dose of ketorolac [37].

\subsection{Surgical techniques}

Shahait et al. have evaluated valveless trocar system during robot-assisted radical prostatectomy and found lower VAS scores compared to standard trocars [38]. Kava et al. looked at the difference in incision technique, transverse or longitudinal, during open radical prostatectomy and found no difference in pain scores or opioid use [39].

Oderda et al. have compared the impact of warmed and humidified $\mathrm{CO} 2$ insufflation with standard $\mathrm{CO} 2$ insufflation. Both groups also received a hot air warming blanket, there was no difference in pain scores [40]. 
One RCT from Yaxley et al. has compared open with robot-assisted prostatectomy. This study found that the robot-assisted group reported significantly less pain during normal activities in the early postoperative period until one week postoperative. There was no difference in postoperative analgesic consumption between the two groups [41]. We also included a metaanalysis from Ilic et al. (in which the article from Yaxley was included) and found that studies evaluating pain after robotic surgery, versus open surgery, documented lower postoperative pain after robot-assisted surgery that also contributed to an improved patient' comfort and a better recovery $[41,42]$.

\subsection{Urinary catheter management}

Martinschek et al. have compared suprapubic catheters and urinary catheters in robot-assisted prostatectomy [43]. They found that suprapubic catheters less bothered patients. However, pain did not differ between the two groups except for postoperative day 5 and 6 , where the suprapubic catheter group presented lower catheter-related pain scores without any difference in overall pain either. Prasad et al. found no difference in pain or side effects between urethral catheter and suprapubic catheter after robot-assisted prostatectomy [44]. One meta-analysis comparing the transurethral versus suprapubic catheter found that there was less postoperative pain in the suprapubic catheter group [45] Another meta-analysis found no conclusive difference. [46]. In a recent study of Lista et al., they compared the effect of early catheter removal on day 3 to day 5 and found a shorter length of hospital stay for the early removal group, together with less discomfort and pain on discharge, without any difference in the incidence of complications [47]. 


\subsection{Anaesthetic techniques}

A pharmacokinetic model for fentanyl administration has been compared to conventional fentanyl dosing regimen. The study showed lower postoperative VAS scores with lower opioid requirements when the pharmacokinetic model was applied [48].

Yoo et al. have compared total intravenous anaesthesia with propofol and remifentanil to desflurane and remifentanil [49]. No difference in VAS scores and opioid demand was documented.

Funcke et al. have evaluated several nociception-monitoring devices (Surgical Pleth Index [SPI], Pupillary Pain Index [PPI], Nociception Level [NoL] or by clinical judgment) and found no difference in opioid consumption [50]. A comparison between a deep neuromuscular block reversed by sugammadex and a moderate block reversed by neostigmine found no difference in shoulder pain, overall pain scores an morphine use [51].

A randomised study has compared a bundle of fast track postoperative care to conventional care after laparoscopic radical prostatectomy, and found lower postoperative pain scores and length of hospital stay in the enhanced rehabilitation group [52]. 


\section{DISCUSSION}

This systematic review included 35 RCTs with a majority of high-quality studies. The included studies were interpreted based on the use of a baseline analgesic technique in the control group and balancing the benefits and adverse effects of the intervention as well as assimilating this information in a clinical context (i.e., in the setting of radical prostatectomy). We thus provide recommendations (Table 1 and Table 2 ) with supporting arguments for and against the use of analgesic interventions for radical prostatectomy.

This systematic review is an update of a previous PROSPECT review published in 2015 [10]. This review stated that there was a significant lack of evidence to determine an optimal pain management protocol in patients undergoing radical prostatectomy. In addition to the expansion of robotic surgery, it seemed legitimate to perform the current review. The recommendations for the current review were built on those of the previous review and supported by the information retrieved from the more recent studies.

Studies confirm that robot-assisted surgery is less painful than open prostatectomy. Based on this statement it seems logical that postoperative analgesic protocols should be at least partly different also in agreement with evidences documented in the literature. Perioperative use of paracetamol is recommended despite limited procedure-specific evidence, based on previous recommendations [10]. COX-2 inhibitors and NSAIDs are recommended based on several studies collected in the previous review [10] and one additional study concerning parecoxib included in the current review, provided there are no contra-indications. NSAIDs have shown to be effective after open surgery and likely after robot-assisted surgery. Systemic lidocaine is 
recommended for open prostatectomy based on two positive studies, one collected in the previous review [53] and one in the current review [17]. The duration of lidocaine infusion should be limited however to the intraoperative and immediate postoperative periods for safety reason. Indeed subcutaneous or intravenous prolonged administration of lidocaine in the postoperative period does not correspond to common usage [17, 54]. Intravenous lidocaine cannot be recommended for minimally invasive surgery due to the lack of evidences. An international consensus statement recently focused on efficacy and safety of intravenous lidocaine infusion [55]. It has been clearly stated that intravenous lidocaine should not be used at the same time as regional anaesthesia.

We do not recommend epidural analgesia despite positive studies published since January 2015 and before [10] because the technique is invasive and conveys a risk of side effects and complications such as hypotension, dural puncture and even epidural haematoma [56]. Caudal block is not recommended because only one negative study has been published on its use [26]. We previously recommended spinal morphine for open radical prostatectomy based on three positive studies [10]. This recommendation is supported by an additional positive study published since, in patients scheduled for open prostatectomy. However, intrathecal morphine administration also induces well-documented adverse side effects such as nausea and vomiting and conveys a risk of respiratory depression. These effects are dose-dependent [57], but lowdoses spinal morphine have not been documented to be effective after prostatectomy, so far. In addition, the duration of the analgesic effect of spinal morphine is not well documented. 
Consequently, we do not recommend spinal morphine as first line analgesic treatment for prostatectomy.

As we retrieved three positives studies, a bilateral transabdominal peritoneal block is recommended in laparoscopic or robotic procedures. In open surgery, studies on TAP block reported conflicting results, so no recommendation could be elaborated in this setting. Wound infiltrations with local anaesthetic agents can be considered for open procedures. On that topic, our updated review retrieved two studies, one of them being an evaluation of a continuous infusion, [28,33] and one positive study was already in the last review [58]. The previous review also retrieved two more studies evaluating Magnesium, with or without local anaesthetic, wound infiltration $[59,60]$. These two studies did not bring enough information to recommend the use of magnesium, but reinforced wound infiltration as analgesic strategy. These analgesic strategies cannot be used at the same time as intravenous lidocaine infusion [55].

Our search did not retrieve any procedure specific evidence on the use of dexamethasone, ketamine, magnesium, clonidine, pregabaline and opioid-free anaesthesia protocol. Dexmedetomidine was evaluated in a single negative study. Despite the lack of procedure specific evidence, we decided to maintain the previous recommendations on dexamethasone, considering the absence of serious side effects [10]. Gabapentin was documented to decrease pain scores and opioid demand in one study but the side effects induced by gabapentin such as sedation, drowsiness or blurred vision could be troublesome in the postoperative period and do not support the routine use of gabapentin based on a single study.

This review updates the recommendations published in 2015 [10], with new recommendations of regional anaesthesia for robot assisted and laparoscopic surgery and 
introducing intravenous lidocaine for open surgery. The use of intrathecal opioids is no longer recommended as first line analgesia.

The included studies have some limitations that keep the conclusions in perspective. Studyprotocols vary in dosing regimens, route of administration, and standard of care in control groups. Some analgesic treatments were not evaluated against a control group that received an adequate analgesic regimen. Most studies included small sample groups, that made the results inconclusive when they showed no difference between groups. In addition, the sample sizes were too limited to draw conclusions concerning the safety profile of the analgesic drugs or techniques in the specific setting of prostatectomy. Eventually other outcomes such as deambulation, lengt of hospital stay, patient satisfaction should be evaluated more systematically. Other limiting factors include selection bias by the primary reviewers. Selection bias could have developed because all studies fulfilling the search requirements were split between two reviewers, and then included or excluded based on Jadad score requirements. This method also allows for human error, where an appropriate study could have been missed by a reviewer and excluded. Some limitation concerning our methodology can be discussed. The Cochrane risk of bias assessment tool, has not been used in this review, as stated in the PROSPECT methodology, other tools were used. Finally, recommendations were not elaborated according to the Grade approach, as the Prospect collaboration uses not only systematic review and grading of the studies, but also Delphi rounds to assess the balance between efficacy and invasiveness of the interventions to provide recommendations adapted to clinical practice. 


\section{CONCLUSIONS}

In summary, an optimal pain management after radical prostatectomy has been identified by this review (Table 1). A balance of the analgesic efficacy and potential risks of the analgesic intervention determine these recommendations. Perioperative pain management for radical prostatectomy should include, unless contraindicated, paracetamol and NSAIDs continued into the postoperative period primarily for their ability to reduce opioid use, and opioids as rescue postoperatively. Intraoperative intravenous infusion of lidocaine is appropriate for open prostatectomy. Wound infiltration is an effective, safe and easy procedure for open procedures while TAP block is effective for robot and laparoscopic procedures.

\section{Financial Support:}

PROSPECT is supported by an unrestricted grant from the European Society of Regional Anaesthesia and Pain Therapy (ESRA). In the past, PROSPECT had received unrestricted grants from Pfizer Inc. New York, NY, USA and Grunenthal, Aachen, Germany.

\section{Disclosure of interests:}

Adrien Lemoine, A Witdouck, Hélène Beloeil has no conflict of interest to declare.Francis Bonnet has received honoraria from Grunenthal, The Medicine Company, Abbott France, and Nordic Pharma France.

\section{Contribution to authorship:}

$\mathrm{AL}$ and $\mathrm{AW}$ conducted the literature search and analysed the retrieved articles with FB and $\mathrm{HB} ; \mathrm{AL}, \mathrm{AW}, \mathrm{FB}$ and $\mathrm{HB}$ wrote the manuscript, which was reviewed and edited by all the other authors who have also participated in the PROSPECT Working Group meetings using the Delphi method and in defining the methodology of the PROSPECT group. 


\section{REFERENCES}

[1] Ilic D, Neuberger M, Djulbegovic M, Dahm P. Screening for prostate cancer. Cochrane Database Syst Rev 2013. https://doi.org/10.1002/14651858.CD004720.pub3.

[2] Heidenreich A, Bastian PJ, Bellmunt J, Bolla M, Joniau S, van der Kwast $T$, et al. EAU guidelines on prostate cancer. part 1: screening, diagnosis, and local treatment with curative intent-update 2013. Eur Urol 2014;65:124-37. https://doi.org/10.1016/j.eururo.2013.09.046.

[3] Tsui C, Klein R, Garabrant M. Minimally invasive surgery: national trends in adoption and future directions for hospital strategy. Surg Endosc 2013;27:2253-7. https://doi.org/10.1007/s00464013-2973-9.

[4] Tan M, Law LS-C, Gan TJ. Optimizing pain management to facilitate Enhanced Recovery After Surgery pathways. Can J Anesth Can Anesth 2015;62:203-18. https://doi.org/10.1007/s12630-0140275-x.

[5] Joshi GP, Schug SA, Kehlet H. Procedure-specific pain management and outcome strategies. Best Pract Res Clin Anaesthesiol 2014;28:191-201. https://doi.org/10.1016/j.bpa.2014.03.005.

[6] D'Alonzo RC, Gan TJ, Moul JW, Albala DM, Polascik TJ, Robertson CN, et al. A retrospective comparison of anesthetic management of robot-assisted laparoscopic radical prostatectomy versus radical retropubic prostatectomy. J Clin Anesth 2009;21:322-8. https://doi.org/10.1016/j.jclinane.2008.09.005.

[7] Woldu SL, Weinberg AC, Bergman A, Shapiro EY, Korets R, Motamedinia P, et al. Pain and analgesic use after robot-assisted radical prostatectomy. J Endourol 2014;28:544-8. https://doi.org/10.1089/end.2013.0783.

[8] Lee B, Schug SA, Joshi GP, Kehlet H. Procedure-Specific Pain Management (PROSPECT) - An update. Best Pract Res Clin Anaesthesiol 2018;32:101-11. https://doi.org/10.1016/j.bpa.2018.06.012.

[9] Joshi GP, Van de Velde M, Kehlet H, the PROSPECT Working Group Collaborators, Pogatzki-Zahn E, Schug $S$, et al. Development of evidence-based recommendations for procedure-specific pain management: PROSPECT methodology. Anaesthesia 2019:anae.14776. https://doi.org/10.1111/anae.14776.

[10] Joshi GP, Jaschinski T, Bonnet F, Kehlet H. Optimal pain management for radical prostatectomy surgery: what is the evidence? BMC Anesthesiol 2015;15:159. https://doi.org/10.1186/s12871015-0137-2.

[11] PRISMA-P Group, Moher D, Shamseer L, Clarke M, Ghersi D, Liberati A, et al. Preferred reporting items for systematic review and meta-analysis protocols (PRISMA-P) 2015 statement. Syst Rev 2015;4:1. https://doi.org/10.1186/2046-4053-4-1.

[12] Jadad AR, Moore RA, Carroll D, Jenkinson C, Reynolds DJM, Gavaghan DJ, et al. Assessing the quality of reports of randomized clinical trials: Is blinding necessary? Control Clin Trials 1996;17:112. https://doi.org/10.1016/0197-2456(95)00134-4.

[13] Schulz KF, Altman DG, Moher D. CONSORT 2010 Statement: updated guidelines for reporting parallel group randomised trials. BMJ 2010;340:c332. https://doi.org/10.1136/bmj.c332.

[14] Myles PS, Myles DB, Galagher W, Boyd D, Chew C, MacDonald N, et al. Measuring acute postoperative pain using the visual analog scale: the minimal clinically important difference and patient acceptable symptom state. Br J Anaesth 2017;118:424-9. https://doi.org/10.1093/bja/aew466.

[15] Wang VC, Preston MA, Kibel AS, Xu X, Gosnell J, Yong RJ, et al. A Prospective, Randomized, DoubleBlind, Placebo-Controlled Trial to Evaluate Intravenous Acetaminophen Versus Placebo in Patients Undergoing Robotic-Assisted Laparoscopic Prostatectomy. J Pain Palliat Care Pharmacother 2019:1-9. https://doi.org/10.1080/15360288.2018.1513436. 
[16] Deniz M, Sertoz N, Erhan E, Ugur G. Effects of preoperative gabapentin on postoperative pain after radical retropubic prostatectomy. J Int Med Res 2012;40:2362-2369. https://doi.org/10.1177/030006051204000635.

[17] Weinberg L, Rachbuch C, Ting S, Howard W, Yeomans M, Gordon I, et al. A randomised controlled trial of peri-operative lidocaine infusions for open radical prostatectomy. Anaesthesia 2016;71:405-410. https://doi.org/10.1111/anae.13368.

[18] Ogrič K., Požar-Lukanović N., Jenko M., Šoštarič M., Spindler-Vesel A. The influence of dexmedetomidine on opioid consumption in radical prostatectomy. Signa Vitae 2017;13:102-7. https://doi.org/10.22514/SV132.112017.16.

[19] Dirkmann D, Groeben H, Farhan H, Stahl DL, Eikermann M. Effects of parecoxib on analgesia benefit and blood loss following open prostatectomy: a multicentre randomized trial. BMC Anesthesiol 2015;15:31. https://doi.org/10.1186/s12871-015-0015-y.

[20] Bae J, Kim H-C, Hong DM. Intrathecal morphine for postoperative pain control following robotassisted prostatectomy: a prospective randomized trial. J Anesth 2017;31:565-71. https://doi.org/10.1007/s00540-017-2356-9.

[21] Nuri Deniz M, Erhan E, Ugur G. Intrathecal morphine reduces postoperative tramadol consumption in patients undergoing radical retropubic prostatectomy: a randomized trial. Eur Rev Med Pharmacol Sci 2013;17:834-838.

[22] Koning MV, de Vlieger R, Teunissen AJW, Gan M, Ruijgrok EJ, de Graaff JC, et al. The effect of intrathecal bupivacaine/morphine on quality of recovery in robot-assisted radical prostatectomy: a randomised controlled trial. Anaesthesia 2019. https://doi.org/10.1111/anae.14922.

[23] Baumunk D, Strang CM, Kropf S, Schafer M, Schrader M, Weikert S, et al. Impact of thoracic epidural analgesia on blood loss in radical retropubic prostatectomy. Urol Int 2014;93:193-201. https://doi.org/10.1159/000360300.

[24] Fant F., Tina E., Sandblom D., Andersson S.-O., Magnuson A., Hultgren-Hörnkvist E., et al. Thoracic epidural analgesia inhibits the neuro-hormonal but not the acute inflammatory stress response after radical retropubic prostatectomy. Br J Anaesth 2013;110:747-57. https://doi.org/10.1093/bja/aes491.

[25] Hwang BY, Kwon JY, Jeon SE, Kim ES, Kim HJ, Lee HJ, et al. Comparison of patient-controlled epidural analgesia with patient-controlled intravenous analgesia for laparoscopic radical prostatectomy. Korean J Pain 2018;31:191-8. https://doi.org/10.3344/kjp.2018.31.3.191.

[26] Chen K, Sim A, Kan AF. The effect of adjunct caudal block on postoperative analgesia in robotassisted laparoscopic radical prostatectomy: A prospective randomized controlled, single blinded pilot study in a tertiary centre. Asian J Urol 2018;5:122-6.

https://doi.org/10.1016/j.ajur.2017.06.009.

[27] Elkassabany N, Ahmed M, Malkowicz SB, Heitjan DF, Isserman JA, Ochroch EA. Comparison between the analgesic efficacy of transversus abdominis plane (TAP) block and placebo in open retropubic radical prostatectomy: a prospective, randomized, double-blinded study. J Clin Anesth 2013;25:459-65. https://doi.org/10.1016/j.jclinane.2013.04.009.

[28] Skjelsager A, Ruhnau B, Kistorp TK, Kridina I, Hvarness H, Mathiesen O, et al. Transversus abdominis plane block or subcutaneous wound infiltration after open radical prostatectomy: a randomized study. Acta Anaesthesiol Scand 2013;57:502-8. https://doi.org/10.1111/aas.12080.

[29] Maquoi I, Joris J, Dresse C, Vandenbosch S, Venneman I, Brichant J, et al. Transversus abdominis plane block or intravenous lignocaine in open prostate surgery: a randomized controlled trial. Acta Anaesthesiol Scand 2016;60:1453-1460. https://doi.org/10.1111/aas.12773.

[30] Dal Moro F., Aiello L., Pavarin P., Zattoni F. Ultrasound-guided transversus abdominis plane block (US-TAPb) for robot-assisted radical prostatectomy: a novel "4-point" technique-results of a 
prospective, randomized study. J Robot Surg 2019;13:147-51. https://doi.org/10.1007/s11701018-0858-6.

[31] Cacciamani G.E., Menestrina N., Pirozzi M., Tafuri A., Corsi P., De Marchi D., et al. Impact of Combination of Local Anesthetic Wounds Infiltration and Ultrasound Transversus Abdominal Plane Block in Patients Undergoing Robot-Assisted Radical Prostatectomy: Perioperative Results of a Double-Blind Randomized Controlled Trial. J Endourol 2019;33:295-301. https://doi.org/10.1089/end.2018.0761.

[32] Taninishi H, Matsusaki T, Morimatsu H. Transversus Abdominis Plane Block Reduced Early Postoperative Pain after Robot-assisted Prostatectomy: a Randomized Controlled Trial. Sci Rep 2020;10:3761. https://doi.org/10.1038/s41598-020-60687-y.

[33] Kristensen B, Fenger-Eriksen C, Pedersen K, Felsby S. Wound infusion of bupivacaine following radical retropubic prostatectomy: a randomised placebo-controlled clinical study. Eur J Anaesthesiol 2013;30:124-128. https://doi.org/10.1097/EJA.0b013e32835c6f25.

[34] Ibrahim A.S., Farrag W.S., Galal Aly M. Ultrasound guided bilateral rectus sheath block and serum TNF- $\alpha$ and IL- 6 after radical prostatectomy: A randomized double blinded study. Egypt J Anaesth 2018;34:139-43. https://doi.org/10.1016/j.egja.2018.07.003.

[35] Ntritsou V, Mavrommatis C, Kostoglou C, Dimitriadis G, Tziris N, Zagka P, et al. Effect of Perioperative Electroacupuncture as An Adjunctive Therapy on Postoperative Analgesia with Tramadol and Ketamine in Prostatectomy: A Randomised Sham-Controlled Single-Blind Trial. Acupunct Med 2014;32:215-22. https://doi.org/10.1136/acupmed-2013-010498.

[36] Weinberg AC, Woldu SL, Bergman A, Roychoudhury A, Patel T, Berg W, et al. Dorsal penile nerve block for robot-assisted radical prostatectomy catheter related pain: a randomized, double-blind, placebo-controlled trial. SpringerPlus 2014;3:181. https://doi.org/10.1186/2193-1801-3-181.

[37] Fuller A, Vanderhaeghe L, Nott L, Martin P, Pautler S. Intravesical ropivacaine as a novel means of analgesia post-robot-assisted radical prostatectomy: a randomized, double-blind, placebocontrolled trial. J Endourol Endourol Soc 2013;27:313-317. https://doi.org/10.1089/end.2012.0191.

[38] Shahait M, Cockrell R, Yezdani M, Yu S, Lee A, McWilliams K, et al. Improved Outcomes Utilizing a Valveless-Trocar System during Robot-assisted Radical Prostatectomy (RARP). JSLS 2019;23. https://doi.org/10.4293/JSLS.2018.00085.

[39] Kava B, Ayyathurai R, Soloway C, Suarez M, Kanagarajah P, Murugesan M. Prospective randomized comparison of the safety, efficacy, and cosmetic outcome associated with mini-transverse and mini-longitudinal radical prostatectomy incisions. Indian J Urol 2010;26:345-349.

[40] Oderda M, Cerutti E, Gontero P, Manetta T, Mengozzi G, Meyer N, et al. The impact of warmed and humidified $\mathrm{CO} 2$ insufflation during robotic radical prostatectomy: Results of a randomized controlled trial. Urologia 2019;86:130-40. https://doi.org/10.1177/0391560319834837.

[41] Yaxley JW, Coughlin GD, Chambers SK, Occhipinti S, Samaratunga H, Zajdlewicz L, et al. Robotassisted laparoscopic prostatectomy versus open radical retropubic prostatectomy: early outcomes from a randomised controlled phase 3 study. The Lancet 2016;388:1057-66. https://doi.org/10.1016/S0140-6736(16)30592-X.

[42] Ilic D, Evans SM, Allan CA, Jung JH, Murphy D, Frydenberg M. Laparoscopic and robotic-assisted versus open radical prostatectomy for the treatment of localised prostate cancer. Cochrane Database Syst Rev 2017;9:CD009625. https://doi.org/10.1002/14651858.CD009625.pub2.

[43] Martinschek A, Pfalzgraf D, Rafail B, Ritter M, Heinrich E, Trojan L. Transurethral versus suprapubic catheter at robot-assisted radical prostatectomy: a prospective randomized trial with 1-year follow-up. World J Urol 2016;34:407-11. https://doi.org/10.1007/s00345-015-1678-1.

[44] Prasad SM, Large MC, Patel AR, Famakinwa O, Galocy RM, Karrison T, et al. Early removal of urethral catheter with suprapubic tube drainage versus urethral catheter drainage alone after 
robot-assisted laparoscopic radical prostatectomy. J Urol 2014;192:89-95. https://doi.org/10.1016/j.juro.2014.01.004.

[45] Li Z, Li K, Wu W, Wang Q, Ma X, Lin C, et al. The comparison of transurethral versus suprapubic catheter after robot-assisted radical prostatectomy: a systematic review and meta-analysis. Transl Androl Urol 2019;8:476-88. https://doi.org/10.21037/tau.2019.08.25.

[46] Li M-X, Cheng P, Yao L, Li H-J, Xun Y-Q, Yan P-J, et al. Suprapubic tube compared with urethral catheter drainage after robot-assisted radical prostatectomy: A systematic review and metaanalysis. Asian J Surg 2019;42:71-80. https://doi.org/10.1016/j.asjsur.2018.08.004.

[47] Lista G, Lughezzani G, Buffi N, Peschechera R, Cardone P, Lazzeri M, et al. Early versus standard catheter removal after complete anatomical reconstruction during robotassisted radical prostatectomy: results from a prospective single-institutional randomized trial (RIPRECA). J Urol 2018;199:e50-.

[48] Jin S-J, Lim H-S, Kwon Y-J, Park S-U, Yi J-M, Chin J-H, et al. Comparison of the Efficacy and Safety of a Pharmacokinetic Model-Based Dosing Scheme Versus a Conventional Fentanyl Dosing Regimen For Patient-Controlled Analgesia Immediately Following Robot-Assisted Laparoscopic Prostatectomy: A Randomized Clinical Trial. Medicine (Baltimore) 2016;95:e2542. https://doi.org/10.1097/MD.0000000000002542.

[49] Yoo Y-C, Bai S-J, Lee K-Y, Shin S, Choi EK, Lee JW. Total intravenous anesthesia with propofol reduces postoperative nausea and vomiting in patients undergoing robot-assisted laparoscopic radical prostatectomy: a prospective randomized trial. Yonsei Med J 2012;53:1197-202. https://doi.org/10.3349/ymj.2012.53.6.1197.

[50] Funcke S, Pinnschmidt HO, Wesseler S, Brinkmann C, Beyer B, Jazbutyte V, et al. Guiding Opioid Administration by 3 Different Analgesia Nociception Monitoring Indices During General Anesthesia Alters Intraoperative Sufentanil Consumption and Stress Hormone Release: A Randomized Controlled Pilot Study. Anesth Analg 2019. https://doi.org/10.1213/ANE.0000000000004388.

[51] Williams WH 3rd, Cata JP, Lasala JD, Navai N, Feng L, Gottumukkala V. Effect of reversal of deep neuromuscular block with sugammadex or moderate block by neostigmine on shoulder pain in elderly patients undergoing robotic prostatectomy. Br J Anaesth 2020;124:164-72. https://doi.org/10.1016/j.bja.2019.09.043.

[52] Magheli A, Knoll N, Lein M, Hinz S, Kempkensteffen C, Gralla O. Impact of fast-track postoperative care on intestinal function, pain, and length of hospital stay after laparoscopic radical prostatectomy. J Endourol Endourol Soc 2011;25:1143-1147. https://doi.org/10.1089/end.2011.0020.

[53] Groudine SB, Fisher HA, Kaufman RPJ, Patel MK, Wilkins LJ, Mehta SA, et al. Intravenous lidocaine speeds the return of bowel function, decreases postoperative pain, and shortens hospital stay in patients undergoing radical retropubic prostatectomy. Anesth Analg 1998;86:235-9. https://doi.org/10.1097/00000539-199802000-00003.

[54] Weibel S, Jelting Y, Pace N, Helf A, Eberhart L, Hahnenkamp K, et al. Continuous intravenous perioperative lidocaine infusion for postoperative pain and recovery in adults. Cochrane Database Syst Rev 2018. https://doi.org/10.1002/14651858.CD009642.pub3.

[55] Foo I, Macfarlane AJR, Srivastava D, Bhaskar A, Barker H, Knaggs R, et al. The use of intravenous lidocaine for postoperative pain and recovery: international consensus statement on efficacy and safety. Anaesthesia 2021;76:238-50. https://doi.org/10.1111/anae.15270.

[56] Freise H, Van Aken HK. Risks and benefits of thoracic epidural anaesthesia. Br J Anaesth 2011;107:859-68. https://doi.org/10.1093/bja/aer339.

[57] Mugabure Bujedo B. A Clinical Approach to Neuraxial Morphine for the Treatment of Postoperative Pain. Pain Res Treat 2012;2012:1-11. https://doi.org/10.1155/2012/612145. 
[58] Bilgin T, Bozlu M, Atici S, Cayan S, Tasdelen B. Wound infiltration with bupivacaine and intramuscular diclofenac reduces postoperative tramadol consumption in patients undergoing radical retropubic prostatectomy: a prospective, double-blind, placebo-controlled, randomized study. Urology 2011;78:1281-1285. https://doi.org/10.1016/j.urology.2011.07.1428.

[59] Tauzin-Fin P, Sesay M, Svartz L, Krol-Houdek M-C, Maurette P. Wound infiltration with magnesium sulphate and ropivacaine mixture reduces postoperative tramadol requirements after radical prostatectomy. Acta Anaesthesiol Scand 2009;53:X464-469. https://doi.org/10.1111/j.13996576.2008.01888.x.

[60] Lee C., Song Y.-K., Jeong H.-M., Park S.-N. The effects of magnesium sulfate infiltration on perioperative opioid consumption and opioid-induced hyperalgesia in patients undergoing robotassisted laparoscopic prostatectomy with remifentanil-based anesthesia. Korean J Anesthesiol 2011;61:244-50. 
Figure 1: PRISMA flow diagram of studies included in this systematic review.

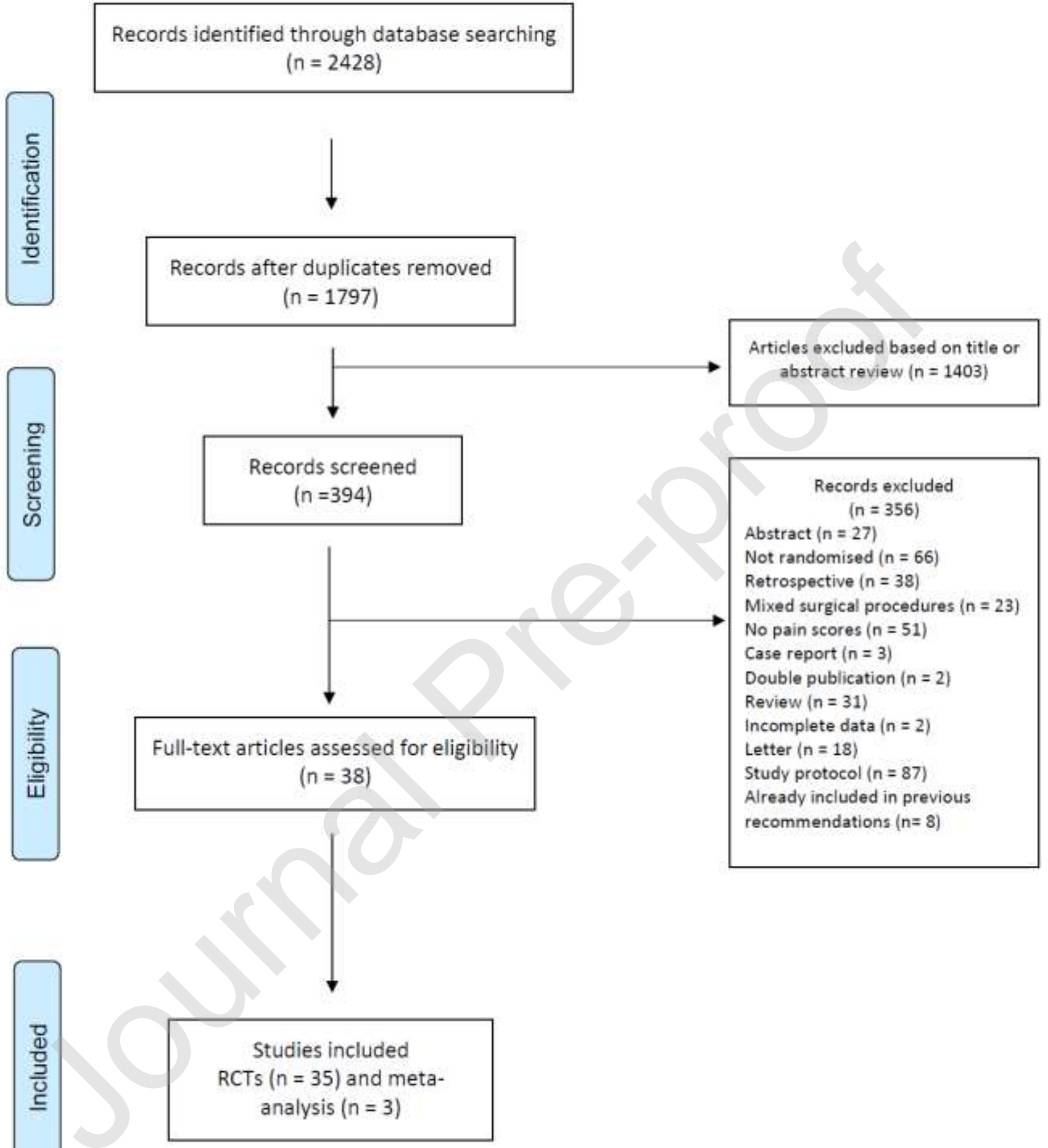


Table 1: Overall recommendations for pain management after radical prostatectomy

\begin{tabular}{|l|l|l|}
\hline Interventions & Recommendations & Grade \\
\hline Paracetamol & $\begin{array}{l}\text { Recommended despite limited } \\
\text { procedure-specific evidence }\end{array}$ & B \\
\hline Systemic lidocaine & $\begin{array}{l}\text { Intraoperative continuous } \\
\text { intravenous infusion of lidocaine is } \\
\text { recommended for open surgery }\end{array}$ & B \\
\hline $\begin{array}{l}\text { Cox-2-selective inhibitors } \\
\text { NSAIDs }\end{array}$ & $\begin{array}{l}\text { Recommended provided there are } \\
\text { no contra-indications }\end{array}$ & A \\
\hline TAP block & $\begin{array}{l}\text { Recommended for } \\
\text { laparoscopic/robotic procedures }\end{array}$ & A \\
\hline Wound infiltration & Recommended for open surgery & B \\
\hline
\end{tabular}

Table 2: Analgesic interventions not recommended for pain management in patients undergoing radical prostatectomy

\begin{tabular}{|l|l|}
\hline Intervention & Reason for exclusion \\
\hline Gabapentine & Limited procedure specific evidence/side effects \\
\hline Dexmedetomidine & Lack of procedure specific evidence \\
\hline Intravesical local anaesthetics & Lack of procedure specific evidence \\
\hline Intrathecal opioid & Not recommended due to the risk of adverse effects \\
\hline Epidural & Unfavourable benefit/risk balance \\
\hline Epidural-caudal block & Lack of procedure specific evidence \\
\hline TAP block & Not recommended for open \\
\hline Rectus sheath block & Lack of procedure specific evidence \\
\hline Electro-acupuncture & Limited procedure specific evidence \\
\hline $\begin{array}{l}\text { Magnesium sulphate wound } \\
\text { infiltration/intravenous }\end{array}$ & Limited procedure specific evidence \\
\hline Penile block & Lack of procedure specific evidence \\
\hline Valveless trocar & Limited procedure specific evidence \\
\hline Transverse vs. longitudinal incision & Lack of procedure specific evidence \\
\hline Intravesical installation ropivacaine & Lack of procedure specific evidence \\
\hline Suprapubic vs. urethral catheter & Lack of procedure specific evidence \\
\hline $\begin{array}{l}\text { Urethral catheter vs. suprapubic and } \\
\text { urethral catheter }\end{array}$ & Lack of procedure specific evidence \\
\hline Early catheter removal & Limited procedure specific evidence \\
\hline CO2 warmed and humidified & Lack of procedure specific evidence \\
\hline Anaesthetic techniques & $\begin{array}{l}\text { No specific recommendations for anaesthetic } \\
\text { technique }\end{array}$ \\
\hline
\end{tabular}


Table 3: Quality assessment and level of evidence assigned to the randomised trials included in this review for analgesia after radical prostatectomy

\begin{tabular}{|c|c|c|c|}
\hline Study & $\begin{array}{l}\text { Quality score } \\
\text { (Allocation concealment: A-D; } \\
\text { randomisation, blinding and } \\
\text { withdrawal score) }\end{array}$ & $\begin{array}{l}\text { Quality Score } \\
\text { (Jadad score) }\end{array}$ & $\begin{array}{l}\text { Level of } \\
\text { evidence }\end{array}$ \\
\hline Wang 2019 [15] & $B$ & 3 & 2 \\
\hline Deniz 2012 [16] & B & 3 & 2 \\
\hline Weinberg 2016 [17] & $A$ & 5 & 1 \\
\hline Ogric 2017 [18] & $\mathrm{C}$ & 1 & 2 \\
\hline Dirkmann 2015 [19] & $A$ & 5 & 1 \\
\hline Bae 2017 [20] & $B$ & 3 & 2 \\
\hline Nuri-Deniz 2013 [21] & $\mathrm{B}$ & 2 & 2 \\
\hline Koning 2019 [22] & $A$ & 4 & 2 \\
\hline Baumunk 2014 [23] & $B$ & 2 & 2 \\
\hline Fant 2013 [24] & $\mathrm{B}$ & 3 & 2 \\
\hline Hwang 2018 [25] & B & 2 & 2 \\
\hline Chen 2018 [26] & 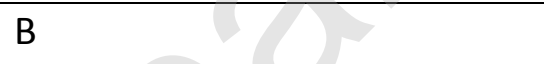 & 2 & 2 \\
\hline $\begin{array}{l}\text { Elkassabany } 2013 \\
\text { [27] }\end{array}$ & $A$ & 5 & 1 \\
\hline Skjelsager 2013 [28] & A & 5 & 1 \\
\hline Maquoi 2016 [29] & $A$ & 5 & 1 \\
\hline Dal Moro 2019 [30] & $A$ & 4 & 1 \\
\hline $\begin{array}{l}\text { Cacciamani } 2019 \\
{[31]}\end{array}$ & $A$ & 5 & 1 \\
\hline Taninishi 2020 [32] & $A$ & 5 & 1 \\
\hline Kristensen 2013 [33] & $A$ & 5 & 1 \\
\hline Ibrahim 2018 [34] & $A$ & 5 & 1 \\
\hline Ntritsou 2014 [35] & B & 4 & 1 \\
\hline
\end{tabular}




\begin{tabular}{|l|l|l|l|}
\hline Weinberg 2014 [36] & A & 4 & 1 \\
\hline Shahait 2019 [38] & C & 1 & 2 \\
\hline Kava 2010 [39] & B & 3 & 2 \\
\hline Fuller 2013 [37] & A & 5 & 1 \\
\hline $\begin{array}{l}\text { Martinschek 2016 } \\
\text { [43] }\end{array}$ & C & 1 & 2 \\
\hline Prasad 2014 [44] & B & 2 & 2 \\
\hline Lista 2020 [47] & C & 2 & 2 \\
\hline Oderda 2019 [40] & C & 3 & 2 \\
\hline Yaxley 2016 [41] & B & 3 & 2 \\
\hline Jin 2016[48] & A & 4 & 1 \\
\hline Yoo 2012 [49] & A & 4 & 1 \\
\hline Funcke 2019 [50] & C & 1 & 2 \\
\hline Williams 2020 [51] & A & 5 & 1 \\
\hline Magheli 2011 [52] & C & 1 & 2 \\
\hline
\end{tabular}


Table S1: Summary of key results from studies evaluating systemic analgesics, systemic analgesic adjuncts, regional analgesia and surgical procedures used to support the recommended interventions in patients after prostate surgery

\begin{tabular}{|c|c|c|c|c|}
\hline Study & $\begin{array}{l}\text { are recommended for radical prostate } \\
\text { Study design }\end{array}$ & 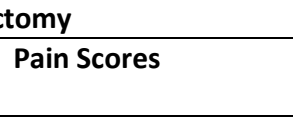 & $\begin{array}{l}\text { Cumulative opioid } \\
\text { doses }\end{array}$ & Baseline Analgesia \\
\hline \multicolumn{5}{|c|}{$\begin{array}{c}\text { Preoperative systemic non-opioid analgesics } \\
\end{array}$} \\
\hline \multicolumn{5}{|c|}{ Paracetamol } \\
\hline Wang 2019 [15] & $\begin{array}{l}\text { Laparoscopic prostatectomy } \\
\text { IV Paracetamol }(n=34) \text { or placebo }(n \\
=41) \text {. }\end{array}$ & NS & NS & $\begin{array}{l}\text { Ketorolac, } \\
\text { ondansetron, } \\
\text { hydromorphone. }\end{array}$ \\
\hline \multicolumn{5}{|l|}{ I.V. Lidocaine } \\
\hline $\begin{array}{l}\text { Weinberg } 2016 \\
\text { [17] }\end{array}$ & $\begin{array}{l}\text { Open radical prostatectomy } \\
\text { Preoperative } 0.075 \mathrm{ml} / \mathrm{kg} \text { lidocaine } 2 \\
\mathrm{mg} / \mathrm{ml} \text { infusion and postoperative } \\
\text { subcutaneous infusion at } 0.075 \\
\mathrm{ml} / \mathrm{kg} / \mathrm{h}(\mathrm{n}=37) \text { vs. saline } 0.9 \%(n= \\
38) .\end{array}$ & $\begin{array}{l}\text { No reduction of pain } \\
\text { scores at rest, or on } \\
\text { coughing, during } 24 \\
h .\end{array}$ & $\begin{array}{l}\text { Lidocaine reduced } 24 \mathrm{~h} \\
\text { morphine consumption. }\end{array}$ & $\begin{array}{l}\text { Paracetamol, } \\
\text { ketorolac, PCA } \\
\text { morphine. }\end{array}$ \\
\hline \multicolumn{5}{|c|}{ Cox-2-selective inhibitors } \\
\hline $\begin{array}{l}\text { Dirkmann } 2015 \\
\text { [19] }\end{array}$ & $\begin{array}{l}\text { Open prostatectomy ( } n=48) \\
\text { Paracoxib } 40 \mathrm{mg} \text { on patient arrival, } \\
\text { repeated every } 12 \mathrm{~h} \\
\text { paracoxib } 20 \mathrm{mg} \text { vs. i.v. placebo. }\end{array}$ & $\begin{array}{l}\text { - Modified-brief pain } \\
\text { inventory-short form } \\
\text { (m-BPI-sf). } \\
\text { - Pain severity (m- } \\
\text { BPI-sf: } 1(1 / 2) \text { vs. } \\
2(2 / 3) \text {, and pain } \\
\text { interference (m-BPI- } \\
\text { sf: } 1(0 / 1) \text { vs. } 1(1 / 3) \text {. }\end{array}$ & $\begin{array}{l}\text { Parecoxib significantly } \\
\text { reduced cumulative } \\
\text { opioid consumption by } \\
24 \%, \text { and reduced } \\
\text { opioid-related side } \\
\text { effects. }\end{array}$ & $\begin{array}{l}\text { PCA morphine for } \\
\text { postoperative pain } \\
\text { (continuous and } \\
\text { bolus dose). }\end{array}$ \\
\hline \multicolumn{5}{|c|}{ Regional anaesthesia } \\
\hline \multicolumn{5}{|l|}{ TAP block } \\
\hline $\begin{array}{l}\text { Dal Moro } 2019 \\
\text { [30] }\end{array}$ & $\begin{array}{l}\text { Robotic prostatectomy } \\
\text { bilateral TAP block ( } 200 \mathrm{ml} \text { of } 2.5 \\
\mathrm{mg} / \mathrm{ml} \text { levobupivacaine }(n=50) ; \text { no } \\
\operatorname{TAPb}(n=50)\end{array}$ & $\begin{array}{l}\text { TAP provided } \\
\text { significant reduction } \\
\text { in NRS at 6, 12, } 18 \\
\text { and } 24 \mathrm{~h} \text {. }\end{array}$ & $\begin{array}{l}\text { Significant reduction of } \\
\text { postoperative } \\
\text { consumption of } \\
\text { tramadol and } \\
\text { ketoprofen in the TAP } \\
\text { group. }\end{array}$ & $\begin{array}{l}\text { Paracetamol } 3 \text { times } \\
\text { a day, rescue } \\
\text { tramadol and } \\
\text { ketoprofen. }\end{array}$ \\
\hline $\begin{array}{l}\text { Cacciamani } \\
2019[31]\end{array}$ & $\begin{array}{l}\text { Robotic prostatectomy } \\
\text { US-TAP group ( } 20 \mathrm{ml} \text { of } 3.5 \\
\mathrm{mg} / \mathrm{ml} \text { Ropivacaine) + Wound } \\
\text { infiltration ( } 20 \mathrm{ml} \text { of } 3.5 \\
\mathrm{mg} / \mathrm{ml} \text { Ropivacaine) ( } \mathrm{n}=57 \text { ) vs. No } \\
\text { TAP but wound infiltration } \\
(20 \mathrm{ml} \text { of } 3.5 \mathrm{mg} / \mathrm{ml} \text { Ropivacaine) ( } \mathrm{n} \\
=43) .\end{array}$ & $\begin{array}{l}\text { US-TAP block group } \\
\text { showed decreased } \\
\text { mean } 24 \text { h NRS, with } \\
\text { a lesser mean NRS } \\
\text { scale at } 11 \text { p.m. } \\
\text { measurement. NS at } \\
\text { POD 1, 2, 3. }\end{array}$ & $\begin{array}{l}\text { US-TAP block group } \\
\text { showed lesser use of } \\
\text { opioid the day of } \\
\text { procedure (the rescue } \\
\text { dose of tramadol). }\end{array}$ & $\begin{array}{l}\text { Paracetamol and } \\
\text { tramadol as rescue }\end{array}$ \\
\hline $\begin{array}{l}\text { Taninishi } 2020 \\
\text { [32] }\end{array}$ & $\begin{array}{l}\text { Robotic prostatectomy } \\
3.75 \mathrm{mg} / \mathrm{ml} \text { ropivacaine }(n=48) \text { vs. } \\
\text { placebo }(n=52)\end{array}$ & $\begin{array}{l}\text { TAP showed a } \\
\text { significant decrease } \\
\text { in NRS scores in rest. } \\
\text { At the time of PACU } \\
\text { discharge no } \\
\text { difference in NRS. }\end{array}$ & NS & $\begin{array}{l}\text { Paracetamol as the } \\
\text { first choice, } 50 \mathrm{mg} \\
\text { flurbiprofen axetil as } \\
\text { the second, and } \\
\text { fentanyl PCA. }\end{array}$ \\
\hline \multicolumn{5}{|c|}{ Wound infiltration } \\
\hline $\begin{array}{l}\text { Kristensen } 2013 \\
\text { [33] }\end{array}$ & $\begin{array}{l}\text { Open radical retropubic } \\
\text { prostatectomy. } \\
\text { A multi-hole plastic catheter } \\
\text { subfascially, bupivacaine } 2.5 \mathrm{mg} / \mathrm{ml}\end{array}$ & NS & $\begin{array}{l}\text { Comparable amounts of } \\
\text { morphine, and } \\
\text { oxycodone. } \\
\text { A significant higher }\end{array}$ & $\begin{array}{l}\text { Systematic } \\
\text { paracetamol and } \\
\text { diclofenac, } \\
\text { additional morphine }\end{array}$ \\
\hline
\end{tabular}




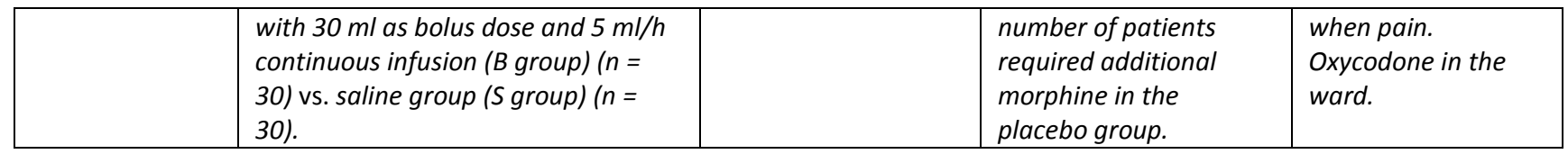

(Results from articles are in Italic) (NS: non-significant difference)

Table S2: Summary of key results from studies evaluating systemic analgesics, systemic analgesic adjuncts, regional analgesia and surgical procedures used to support the not recommended interventions in patients after prostate surgery

\begin{tabular}{|c|c|c|c|c|}
\hline Study & Study design & Pain Scores & $\begin{array}{l}\text { Cumulative opioid } \\
\text { doses }\end{array}$ & Baseline Analgesia \\
\hline \multicolumn{5}{|c|}{ Preoperative systemic non-opioid analgesics } \\
\hline \multicolumn{5}{|l|}{ Gabapentin } \\
\hline Deniz 2012 [16] & $\begin{array}{l}\text { Open radical retropubic prostatectomy } \\
\text { Gabapentin } 900 \mathrm{mg} \text { per os } 2 \text { h before } \\
\text { surgery }(n=25) \text { vs. no gabapentin }(n= \\
\text { 25). }\end{array}$ & $\begin{array}{l}\text { Pain scores significantly } \\
\text { lower in the gabapentin } \\
\text { group compared with } \\
\text { controls at } 45 \text { min, } 60 \text { min } \\
\text { and } 2 \text { h postoperatively. }\end{array}$ & $\begin{array}{l}\text { The mean cumulative } \\
\text { tramadol } \\
\text { consumption at } 24 \mathrm{~h} \\
\text { was comparable in } \\
\text { the two groups. The } \\
\text { number of patients } \\
\text { who required rescue } \\
\text { analgesia was lower } \\
\text { in the gabapentin } \\
\text { group than in the } \\
\text { control group. }\end{array}$ & $\begin{array}{l}\text { Tramadol PCA (bolus } 50 \\
\text { mg, followed by } 20 \mathrm{mg} \text { on } \\
\text { demand, lockout } 15 \mathrm{~min} \text { ), } \\
\text { rescue is paracetamol, } \\
\text { diclofenac. }\end{array}$ \\
\hline \multicolumn{5}{|l|}{ Dexmedetomidine } \\
\hline Ogric 2017 [18] & $\begin{array}{l}\text { Open radical prostatectomy } \\
\text { Dexmedetomidine }(0.3 \mu \mathrm{g} / \mathrm{kg} / \mathrm{h}) \text { was } \\
\text { started with intravenous line insertion } \\
\text { and continued until wound closure. }\end{array}$ & NS & NS & $\begin{array}{l}\text { Paracetamol } \\
\text { PCA piritramide }\end{array}$ \\
\hline \multicolumn{5}{|c|}{ Regional anaesthesia } \\
\hline \multicolumn{5}{|c|}{ Preoperative Intrathecal morphine } \\
\hline Bae 2017 [20] & $\begin{array}{l}\text { Laparoscopic prostatectomy } \\
300 \mu g \text { intrathecal (IT) morphine with } \\
\text { IV-PCA }(n=15) \text { vs. IV-PCA only (1mg } \\
\text { morphine } / \mathrm{ml})(n=15) \text {. }\end{array}$ & $\begin{array}{l}\text { NPSs until postoperative } 24 \\
h \text { were significantly lower in } \\
\text { the ITM group. } \\
\text { No difference in the NPS at } \\
\text { rest and on coughing } \\
\text { between the two groups } \\
\text { after the first postoperative } \\
24 h \text {. }\end{array}$ & $\begin{array}{l}\text { Postoperative } \\
\text { morphine } \\
\text { consumption was } \\
\text { significantly lower in } \\
\text { the ITM group at } 12 \\
\text { and } 24 \mathrm{~h} \\
\text { postoperatively. }\end{array}$ & Morphine PCA \\
\hline Nuri-Deniz 2013 [21] & $\begin{array}{l}\text { Open radical prostatectomy IT } \\
\text { morphine }(200 \mu \mathrm{g}) \text { vs. no intrathecal } \\
\text { morphine }\end{array}$ & $\begin{array}{l}\text { VAS scores were lower in } \\
\text { the IT morphine group } \\
\text { compared to the control } \\
\text { group in the first } 12 \mathrm{~h} \\
\text { postoperatively. }\end{array}$ & $\begin{array}{l}\text { Tramadol } \\
\text { consumption and } \\
\text { postoperative nausea } \\
\text { were lower in the IT } \\
\text { morphine group. } \\
\text { Less patients in the IT } \\
\text { morphine required } \\
\text { rescue analgesia. }\end{array}$ & $\begin{array}{l}\text { Tramadol PCA and } \\
\text { paracetamol and } \\
\text { diclofenac. }\end{array}$ \\
\hline
\end{tabular}




\begin{tabular}{|c|c|c|c|c|}
\hline Koning 2019 [22] & $\begin{array}{l}\text { Robot-assisted radical prostatectomy } \\
\text { IT } 12.5 \mathrm{mg} \text { bupivacaine } / 300 \mu \mathrm{g} \\
\text { morphine vs. sham injection and } \\
\text { intravenous loading dose of } 0.1 \mathrm{mg} \cdot \mathrm{kg}^{-1} \\
\text { morphine. }\end{array}$ & $\begin{array}{l}\text { Intervention group had } \\
\text { lower pain scores during } \\
\text { exertion; NRS 3 (1-6 [0-9]) } \\
\text { vs. } 5 \text { (3-7 [0-9]). }\end{array}$ & $\begin{array}{l}\text { Intervention group } \\
\text { received less } \\
\text { morphine; } 2 \mathrm{mg} \mathrm{(1-7} \\
[0-41 \mathrm{mg}]) \text { vs. } 15 \mathrm{mg} \\
(12-20[8-61 \mathrm{mg}])\end{array}$ & $\begin{array}{l}\text { Paracetamol up to } 4000 \\
\text { mg/day and metamizole } \\
1000 \mathrm{mg}+\text { Morphine PCA }\end{array}$ \\
\hline \multicolumn{5}{|l|}{ Epidural } \\
\hline Baumunk 2014 [23] & $\begin{array}{l}\text { Radical retropubic prostatectomy } \\
\text { Thoracic epidural analgesia with } \\
\text { general analgesia }(n=116) \text { vs. general } \\
\text { anaesthesia }(n=119) \text {. }\end{array}$ & $\begin{array}{l}\text { NRS scores were significant } \\
\text { lower on the first } \\
\text { postoperative day TEA with } \\
\text { general anaesthesia. }\end{array}$ & NS & / \\
\hline Fant 2013 [24] & $\begin{array}{l}\text { Radical retropubic prostatectomy } \\
\text { Systemic opioid based analgesia }(n= \\
14) \text { vs. thoracic epidural based }(n=12) \text {. }\end{array}$ & $\begin{array}{l}\text { Incision pain significantly } \\
\text { lower in the epidural group } \\
\text { on arrival in the PACU and } \\
\text { during the first } 8 \mathrm{~h} \text {. } \\
\text { Deep pain and pain on } \\
\text { coughing also significantly } \\
\text { lower in the epidural Group } \\
\text { at } 0 h, 4 h \text {, and } 8 h \\
\text { Pain on coughing lower } \\
\text { even at } 24 h \text {. }\end{array}$ & $\begin{array}{l}\text { Significantly lower } \\
\text { consumption of } \\
\text { intraoperative opiates } \\
\text { and inhaled agents in } \\
\text { the epidural Group } E \text {. }\end{array}$ & Morphine PCA vs. PCEA. \\
\hline Hwang 2018 [25] & $\begin{array}{l}\text { Laparoscopic radical prostatectomy. } \\
\text { Comparison of patient-controlled } \\
\text { epidural analgesia }(n=17) \text { with patient- } \\
\text { controlled intravenous analgesia ( } n= \\
\text { 19). }\end{array}$ & NS & $\begin{array}{l}\text { Additional analgesics } \\
\text { counts in the PCEA } \\
\text { group were less than } \\
\text { those in the PCIA } \\
\text { group. }\end{array}$ & $\begin{array}{l}\text { Oxycodone and nefopam } \\
\text { in PCA vs. ropivacaine and } \\
\text { morphine in PCEA. }\end{array}$ \\
\hline \multicolumn{5}{|l|}{ Epidural Caudal block } \\
\hline Chen 2018 [26] & $\begin{array}{l}\text { Robot-assisted prostatectomy } \\
\text { caudal block } 20 \mathrm{ml} 5 \mathrm{mg} / \mathrm{ml} \text { ropivacaïne } \\
\text { ( } n=20 \text { ) vs. standard analgesia }(n=20) \\
\text { intravenous morphine, intramuscular } \\
\text { pethidine as well as oral tramadol. }\end{array}$ & NS & NS & $\begin{array}{l}\text { Intravenous morphine, } \\
\text { intramuscular pethidine } \\
\text { as well as oral tramadol. }\end{array}$ \\
\hline \multicolumn{5}{|l|}{ TAP block } \\
\hline Elkassabany 2013 [27] & $\begin{array}{l}\text { Open retropubic prostatectomy } \\
\text { TAP block }(n=16) \text { vs. } \mathrm{NaCl} 0.9 \%(n= \\
\text { 16). }\end{array}$ & $\begin{array}{l}\text { Lower VAS scores on } \\
\text { admission in PACU, at } 1 \mathrm{~h}, 2 \\
h \text {, and } 6 \mathrm{~h} \text { in the TAP block } \\
\text { group. }\end{array}$ & $\begin{array}{l}\text { Opioid requirements } \\
\text { lower in the TAP } \\
\text { group at } 1 \text { and 6-h } \\
\text { intervals. At } 2 \text { and 24- } \\
\text { h intervals, morphine } \\
\text { requirements were } \\
\text { not statistically } \\
\text { different. }\end{array}$ & $\begin{array}{l}\text { Ketorolac, at the end of } \\
\text { surgery all patients } \\
\text { received PCA morphine. }\end{array}$ \\
\hline Skjelsager 2013 [28] & $\begin{array}{l}\text { Open radical prostatectomy } \\
\text { TAP group ( } 40 \mathrm{ml} \text { ropivacaine } 7.5 \\
\mathrm{mg} / \mathrm{ml} \text { and wound infiltration }(40 \mathrm{ml} \\
\text { ropivacaine } 7.5 \mathrm{mg} / \mathrm{ml})(n=23) \mathrm{vs} \text {. } \\
\text { Placebo TAP and placebo wound } \\
\text { infiltration }(n=25) \text { vs. infiltration group } \\
\text { and placebo TAP }(n=25) \text {. }\end{array}$ & NS & NS & $\begin{array}{l}\text { Preoperatively, all } \\
\text { patients received oral } \\
\text { gabapentin, ibuprofen } \\
\text { and paracetamol, } \\
\text { followed by oral } \\
\text { paracetamol and } \\
\text { ibuprofen at regular } \\
\text { doses and intervals, and } \\
\text { IV PCA morphine from } 0 \mathrm{~h} \\
\text { to } 24 \mathrm{~h} \text { postoperatively. } \\
\text { If inadequate, additional } \\
\text { boluses of } 2.5 \text { mg IV } \\
\text { morphine during the first } \\
\text { postoperative hour until } \\
\text { adequate analgesia was } \\
\text { obtained. }\end{array}$ \\
\hline Maquoi 2016 [29] & $\begin{array}{l}\text { Open radical prostatectomy } \\
\text { TAP block and intravenous bolus of }\end{array}$ & NS & NS & $\begin{array}{l}\text { Intraoperative } 2 \mathrm{~g} \\
\text { paracetamol, recovery } \mathrm{IV}\end{array}$ \\
\hline
\end{tabular}




\begin{tabular}{|c|c|c|c|c|}
\hline & $\begin{array}{l}\text { saline with continuous infusion }(n=34) \\
\text { vs. bolus of intravenous lignocaine wit } \\
\text { continuous infusion ( } n=33 \text { ) vs. placebo } \\
\text { TAP and infusion ( } n=34) \text {. }\end{array}$ & & & $\begin{array}{l}\text { piritramide, on ward } \\
\text { paracetamol, rescue } \\
\text { patient controlled } \\
\text { analgesia. }\end{array}$ \\
\hline \multicolumn{5}{|l|}{ Rectus sheat block } \\
\hline Ibrahim 2018 [34] & $\begin{array}{l}\text { Open radical prostatectomy } \\
\text { Placement of rectus sheath block (RSB) } \\
\text { with } 20 \mathrm{ml} \text { of bupivacaine }(n=25) \text { on } \\
\text { each side vs. } 20 \mathrm{ml} \mathrm{NaCl} 0.9 \% \text { on each } \\
\text { side }(n=25) .\end{array}$ & $\begin{array}{l}\text { Mean VAS during first } \\
\text { postoperative day was } \\
\text { significantly lower in group } \\
\text { RSB. }\end{array}$ & $\begin{array}{l}\text { Mean value of total } \\
\text { morphine consumed } \\
\text { by the patients during } \\
\text { the first day was } \\
\text { significantly lower. }\end{array}$ & $\begin{array}{l}\text { Paracetamol and } \\
\text { ketorolac, morphine as } \\
\text { rescue. }\end{array}$ \\
\hline \multicolumn{5}{|l|}{ Electroacupuncture } \\
\hline Ntritsou 2014 [35] & $\begin{array}{l}\text { Open radical prostatectomy } \\
\text { Electroacupuncture applied bilaterally } \\
\text { during closure with tramadol and } \\
\text { ketamine }(n=37) \text { vs. sham acupuncture } \\
\text { with tramadol and ketamine }(n=38) \text {. }\end{array}$ & $\begin{array}{l}\text { Pain scores on the NRS and } \\
S F \_M P Q \text { were significantly } \\
\text { lower and electronic } \\
\text { pressure algometer } \\
\text { measurements were } \\
\text { significantly higher in the } \\
\text { EA group than in the } \\
\text { control group at all } \\
\text { assessments. }\end{array}$ & $\begin{array}{l}\text { A significant decrease } \\
\text { was detected in the } \\
\text { total amount of } \\
\text { analgesia. }\end{array}$ & $\begin{array}{l}\text { Parecoxib IV } 1 \mathrm{~h} \text { before } \\
\text { the end of surgery and } \\
\text { paracetamol IV } 30 \mathrm{~min} \\
\text { before. } \\
\text { Both groups received an } \\
\text { IV bolus of tramadol and } \\
\text { ketamine } 30 \text { min before } \\
\text { the end of surgery. } \\
\text { Administration was } \\
\text { continued by IV infusion } \\
\text { of tramadol and ketamine } \\
\text { via an adjustable flow } \\
\text { disposable pump. The } \\
\text { dose of ketamine was } \\
\text { subanaesthetic and did } \\
\text { not exceed } 300 \text {-mg/ } 24 \mathrm{~h} \text {. } \\
\text { Tramadol and morphine } \\
\text { as rescue. }\end{array}$ \\
\hline \multicolumn{5}{|l|}{ Penile block } \\
\hline Weinberg 2014 [36] & $\begin{array}{l}\text { Robotic-assisted laparoscopic } \\
\text { prostatectomy } \\
\text { Dorsal penile nerve block with } \\
\text { bupivacaine vs. saline injection. }\end{array}$ & $\begin{array}{l}\text { Abdominal pain at 6-hour } \\
\text { time-point was significantly } \\
\text { lower. }\end{array}$ & NS & $\begin{array}{l}\text { Paracetamol according to } \\
\text { pain, ketolorac, } \\
\text { hydromorphone. }\end{array}$ \\
\hline \multicolumn{5}{|l|}{ Surgical Technique } \\
\hline Shahait 2019 [38] & $\begin{array}{l}\text { Laparoscopic prostatectomy } \\
100 \text { patients using valveless trocar } \\
\text { system, } 100 \text { standard trocars. }\end{array}$ & $\begin{array}{l}\text { VTS group had less pain } \\
\text { intensity compared to the } \\
\text { control in the first } 18 \text { hours. }\end{array}$ & NS & $\begin{array}{l}\text { TAP block at the end of } \\
\text { surgery with } 5 \mathrm{ml} \\
\text { bupivacaine bilaterally for } \\
\text { a total of } 10 \mathrm{ml} \text {. } \\
\text { Postoperative pain } \\
\text { control medication with } \\
\text { ketorolac. } \\
\text { Breakthrough pain } \\
\text { managed with } \\
\text { paracetamol and opioid- } \\
\text { based medications. }\end{array}$ \\
\hline Kava 2011 [39] & $\begin{array}{l}\text { Open radical prostatectomy } \\
\text { Transverse longitudinal incision }(n=27) \\
\text { vs. longitudinal incision }(n=27) \text {. }\end{array}$ & NS & NS & $\begin{array}{l}\text { Morphine PCA until day } 1 \text {, } \\
\text { then oxycodone. }\end{array}$ \\
\hline Fuller 2013 [37] & $\begin{array}{l}\text { Robot-assisted laparoscopic } \\
\text { prostatectomy } \\
\text { Intravesical administration of } \\
\text { ropivacaine compared to placebo. }\end{array}$ & NS & $\begin{array}{l}\text { Cumulative dose of } \\
\text { ketorolac significantly } \\
\text { less in the treatment } \\
\text { group, no difference } \\
\text { regarding the } \\
\text { cumulative dose of } \\
\text { morphine. }\end{array}$ & $\begin{array}{l}\text { Paracetamol and } \\
\text { ketorolac. }\end{array}$ \\
\hline \multicolumn{5}{|l|}{ Catheter } \\
\hline Martinschek 2016 [43] & Robot-assisted radical prostatectomy & Pain caused by the catheter & I & I \\
\hline
\end{tabular}




\begin{tabular}{|c|c|c|c|c|}
\hline & $\begin{array}{l}\text { Bladder drainage wit urethral catheter } \\
(n=35) \text { vs. suprapubic catheter }(n= \\
27) .\end{array}$ & $\begin{array}{l}\text { was significantly lower for } \\
\text { the suprapubic catheter } \\
\text { groups on POD } 5 \text { and } 6 .\end{array}$ & & \\
\hline Prasad 2014 [44] & $\begin{array}{l}\text { Robot-assisted radical prostatectomy } \\
\text { Suprapubic tube drainage with early } \\
\text { removal of urethral catheter ( } n=29) \text { vs. } \\
\text { transurethral catheter }(n=29)\end{array}$ & NS & / & $\begin{array}{l}\text { Paracetamol alternating } \\
\text { with oral ibuprofen. }\end{array}$ \\
\hline Lista 2020 [47] & $\begin{array}{l}\text { Robot-assisted radical prostatectomy } \\
\text { Urethral catheter removal on day } 3 \text { vs. } \\
\text { day } 5 .\end{array}$ & $\begin{array}{l}\text { Urethral discomfort and } \\
\text { pain at discharge was } \\
\text { significantly higher in group } \\
2 .\end{array}$ & / & / \\
\hline Oderda 2019 [40] & $\begin{array}{l}\text { Robot-assisted radical prostatectomy } \\
\text { Warmed and humidified } \mathrm{CO} 2 \\
\text { insufflation vs. standard } \mathrm{CO} 2 \\
\text { insufflation. }\end{array}$ & NS & / & $\begin{array}{l}\text { Postoperative analgesia: } \\
\text { continuous infusion of } \\
\text { tramadol } 300 \mathrm{mg} / \text { day by } \\
\text { elastomeric pump and } \\
\text { paracetamol } 1 \mathrm{~g} / 8 \mathrm{~h} \\
\text { bolus IV for } 48 \text { hours. } \\
\text { Rescue therapy consisted } \\
\text { of ketorolac } 30 \mathrm{mg} \text { bolus } \\
\mathrm{IV} \text {. }\end{array}$ \\
\hline \multicolumn{5}{|l|}{ Fast track } \\
\hline Magheli 2011 [52] & $\begin{array}{l}\text { Laparoscopic radical prostatectomy } \\
\text { conventional }(n=25) \text { with PCA } \\
\text { piritramide vs. fast-track postoperative } \\
\text { care }(n=25) \text { with high dose COX-2 } \\
\text { inhibitors. }\end{array}$ & $\begin{array}{l}\text { Fast-track patients showed } \\
\text { steeper decreases in resting } \\
\text { pain and lower overall } \\
\text { levels of pain during } \\
\text { mobilization/ambulation. }\end{array}$ & & $\begin{array}{l}\text { Fast track: Cox-2 inhibitor } \\
\text { etoricoxib } \\
\text { Conventional group: PCA } \\
\text { piritramide. }\end{array}$ \\
\hline \multicolumn{5}{|c|}{ Robot/Laparoscopic vs. Open } \\
\hline Yaxley 2016 [41] & $\begin{array}{l}\text { Robot-assisted radical prostatectomy ( } n \\
=163 \text { ) vs. open radical retropubic } \\
\text { prostatectomy ( } n=163) \text {. }\end{array}$ & $\begin{array}{l}\text { Significant differences for } \\
\text { pain in the in the robot- } \\
\text { assisted laparoscopic } \\
\text { prostatectomy group in the } \\
\text { early postoperative period } \\
\text { (24 h and } 1 \text { week). }\end{array}$ & / & / \\
\hline \multicolumn{5}{|c|}{ Anaesthetic technique } \\
\hline $\operatorname{Jin} 2016$ [48] & $\begin{array}{l}\text { Robot-assisted prostatectomy } \\
\text { Fentanyl Pharmacokinetic model-based } \\
\text { dosing scheme to achieve a targeted } \\
\text { concentration. } 20 \mathrm{mcgr} / \mathrm{h} \text { continuous, } \\
\text { to } 10 \mathrm{mcgr} / \mathrm{h}(B)(n=36) \text { vs. } \\
\text { conventional dosing regimen for } \\
\text { intravenous PCA. Bolus } 10 \mathrm{mcgr} \\
\text { fentanyl, lockout } 10 \mathrm{~min}(\mathrm{~A})(n=34) .\end{array}$ & $\begin{array}{l}\text { VAS scores at } 0.5,1,4 \text {, and } \\
\text { were significantly lower in } \\
\text { the pharmacokinetic model- } \\
\text { based group. }\end{array}$ & $\begin{array}{l}\text { Lower fentanyl } \\
\text { consumption. }\end{array}$ & PCA fentanyl. \\
\hline Yoo 2012 [49] & $\begin{array}{l}\text { Robot-assisted radical prostatectomy } \\
\text { Total intravenous anaesthesia }(n=31) \\
\text { vs. balanced anaesthesia with } \\
\text { desflurane }(n=31) \text {. }\end{array}$ & NS & NS & $\begin{array}{l}\text { PCA fentanyl, rescue } \\
\text { analgesic ketorolac. }\end{array}$ \\
\hline Funcke 2019 [50] & $\begin{array}{l}\text { Open radical prostatectomy } \\
\text { Sufentanil administration guided by } \\
\text { analgesia monitoring devices or clinical } \\
\text { control. }\end{array}$ & NS & NS & $\begin{array}{l}\text { Metamizole and clonidine } \\
\text { at the end of surgery, } \\
\text { then piritramide bolus. }\end{array}$ \\
\hline Williams 2020 [51] & $\begin{array}{l}\text { Robotic prostatectomy } \\
\text { Reversal of deep neuromuscular block } \\
\text { with sugammadex or moderate block } \\
\text { with neostigmine. }\end{array}$ & NS & NS & Morphine use in PACU. \\
\hline
\end{tabular}


